УДК 351.74“1939/1945”

DOI: 10.33099/2707-1383-2020-35-1-73-84

Ходанович О. Л., кандидат історичних наук, дочент, професор кафедри теорії та історії держави і права

Національної академії Служби безпеки України (м. Київ)

ORCID: 0000-0002-4829-0997

\title{
ОРГАНІЗАЦІЙНА ПЕРЕБУДОВА РАДЯНСЬКИХ ОРГАНІВ ДЕРЖАВНОЇ БЕЗПЕКИ В УКРАЇНІ У ПЕРІОД ДРУГОЇ СВІТОВОЇ ВІЙНИ.
}

\begin{abstract}
У статті розглядаються організаиійно-правові засади перебудови органів держбезпеки з початком Другої світової війни. Висвітлюється організаційний стан та заходи органів державної безпеки під час німецькорадянської війни.

Ключові слова: органи держбезпеки, Особлива група, 4-ті відділи, 4-те управління НКВС, органи військової контррозвідки, зафронтова робота, оперативне забезпечення партизанського руху, розвідувально-диверсійні onepauiii.
\end{abstract}

Воєнно-політична обстановка в період Другої світової війни обумовлювала організаційно-структурні зміни радянських органів державної безпеки в Україні.

Історіографічна палітра вітчизняних досліджень із історії радянських спецслужб в Україні в період Другої світової війни досить широка. Це археографічні дослідження, публікації загального характеру, дослідження карально-репресивної діяльності та біографічного характеру. Найбільш відповідають задекларованій темі статті наукові доробки функціонування радянських органів державної безпеки. Нормативно-правові основи діяльності досліджено в дисертаційних дослідженнях Л. Бородича, О. Олійника, О. Лебедєва, статтях О. Божка, О. Калюка. Створення радянських органів державної безпеки на Західній Україні висвітлено в статтях Д. Вєдєнєєва, І. Ільошіна, О. Пшеничного. Проаналізовано вплив оперативної обстановки під час війни на формування структур військової розвідки в дисертації В. Бихова, особливості контррозвідувальної протидії німецькій агентурі досліджено в роботах А.Чайковського. У публікаціях Д. Вєдєнєєва, Г. Биструхіна проаналізовано особливості зафронтової роботи та організації радянськими спецслужба- 
ми партизанської боротьби в тилу противника. Проте період Другої світової війни й досі залишається одним із досліджуваних етапів історії радянських спецслужб.

Метою запропонованої статті є спроба узагальнення наукового доробку щодо процесу перебудови радянських органів державної безпеки в Україні в період Другої світової війни; розглянути організаційно-правові засади перебудови та заходи органів держбезпеки 3 початком Другої світової війни та за умов воєнного часу.

Реалізація планів розчленування Польщі Німеччиною та СРСР у вересні 1939 року, радянізація приєднаних до СРСР територій, розгортання розвідувальної та контррозвідувальної діяльності в нових умовах потребували зміни організаційно-штатної структури, оновлення форм і методів агентурно-оперативної роботи радянських органів державної безпеки. Відбулася розбудова мережі органів держбезпеки на західноукраїнських землях (ЗУЗ), приєднаних до СРСР у 1939-1940 рр. відповідно до наказу № 001064 наркома внутрішніх справ СРСР Л. Берії від 8 вересня 1939 p. про оперативне забезпечення військових дій проти Польщі. За цим наказом наркомати внутрішніх справ БРСР та УРСР отримали завдання створити “оперативно-чекістські” групи зі співробітників республіканських НКВС, прикордонних військ. НКВС УРСР на базі Київського військового округу було сформовано 4 групи (по 50-70 співробітників, 5-а група - залишилася у стадії формування), які поділялися на територіальні підгрупи по 7-12 співробітників. Основне завдання опергруп - формувати по мірі просування Червоної армії територіальні органи НКВС - визначала директива НКВС СРСР № 720 від 15 вересня 1939 р. Одним із провідних оперативно-службових завдань органів НКВС відразу ж стало протиборство з підпільною мережею ОУН. У грудні 1939 р. опергрупи стали основою створення обласних управлінь НКВС у Волинській, Дрогобицькій, Львівській, Рівненській, Станіславській, Тернопільській областях (відповідно до наказів наркома внутрішніх справ НКВС УРСР № 001359 від 6 грудня та № 00208 від 25 грудня 1939 р.). У серпні 1940 р. створюється УНКВС у Чернівецькій області.

За постановою політбюро ЦКВКП(б) від 3 лютого 1941 р. зі складу НКВС СРСР було виділено Народний комісаріат державної безпеки СРСР. Зі створенням Наркомату державної безпеки (НКДБ) створюються його республіканські і обласні управління (УНКДБ).

Постановою ЦК ВКП(б) і РНК СРСР від 8 лютого 1941 р. на базі особливого відділу НКВС СРСР були створені 3-ті управління (органи військової контррозвідки) наркоматів оборони та військово-морського флоту СРСР.

Перші дні війни на території України були пов'язані зі вжиттям заходів державним керівництвом СРСР, безпосередньо керівництвом НКВС і НКДБ щодо реорганізації за умов воєнного стану. Створювалися структури спе- 


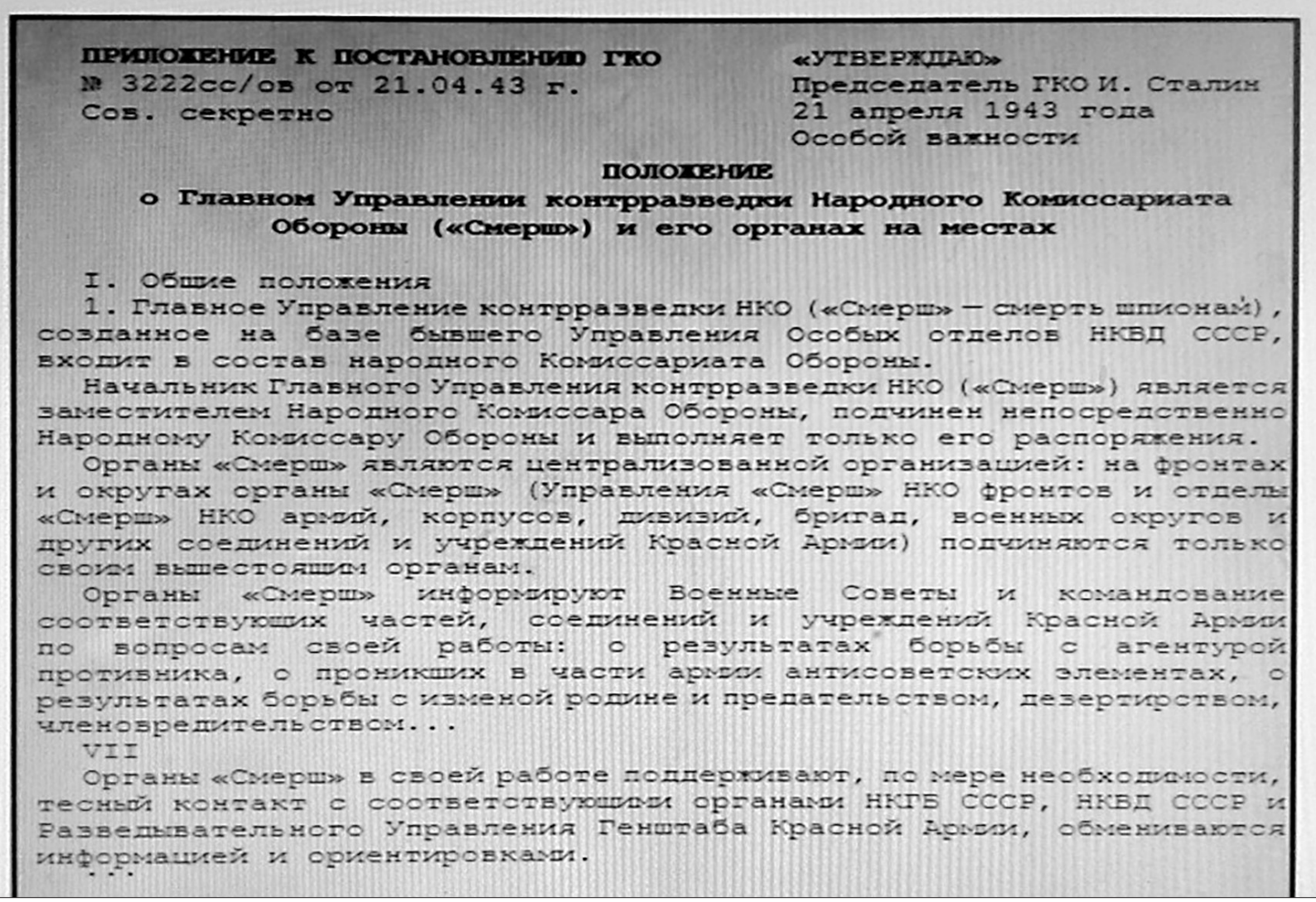

ціальних органів воєнного часу. Указ Президії Верховної Ради СРСР від 22 червня 1941 р. "Про воєнний стан" зобов'язував місцеві органи державної влади надавати допомогу військовому керівництву у використанні сил і засобів для оборони держави, підтримання безпеки і громадського порядку.

За наказом НКВС СРСР від 25 червня 1941 р. "Про заходи по боротьбі з парашутними десантами і диверсантами у прифронтовій полосі" створювались винищувальні батальйони по боротьбі 3 парашутними десантами і диверсантами противника при міських, районних та повітових відділах (відділеннях) НКВС. Начальниками цих батальйонів призначались оперативні працівники НКВС, переважно 3 прикордонних i внутрішніх військ та оперативних працівників міліції; організовувалися гру- пи сприяння винищувальним батальйонам, які повинні були функціонувати в районах за місцем своєї основної діяльності (радянські господарства, окремі промислові підприємства). Відповідні постанови у дводенний строк були видані обласними та районними комітетами КП(б) України.

Директиви НКДБ СРСР № 136 від 24 червня та № 168 від 1 липня 1941 р. визначали завдання на військовий час розгорнути спільно з НКВС СРСР боротьбу з парашутними десантами, диверсійними групами противника, формувати склад невеликих резидентур для осідання на окупованій території, забезпечення конспірації, ведення диверсійно-підривної роботи.

3-те Управління (органи військової контррозвідки) Наркомату оборони СРСР, яке було створено в люто- 


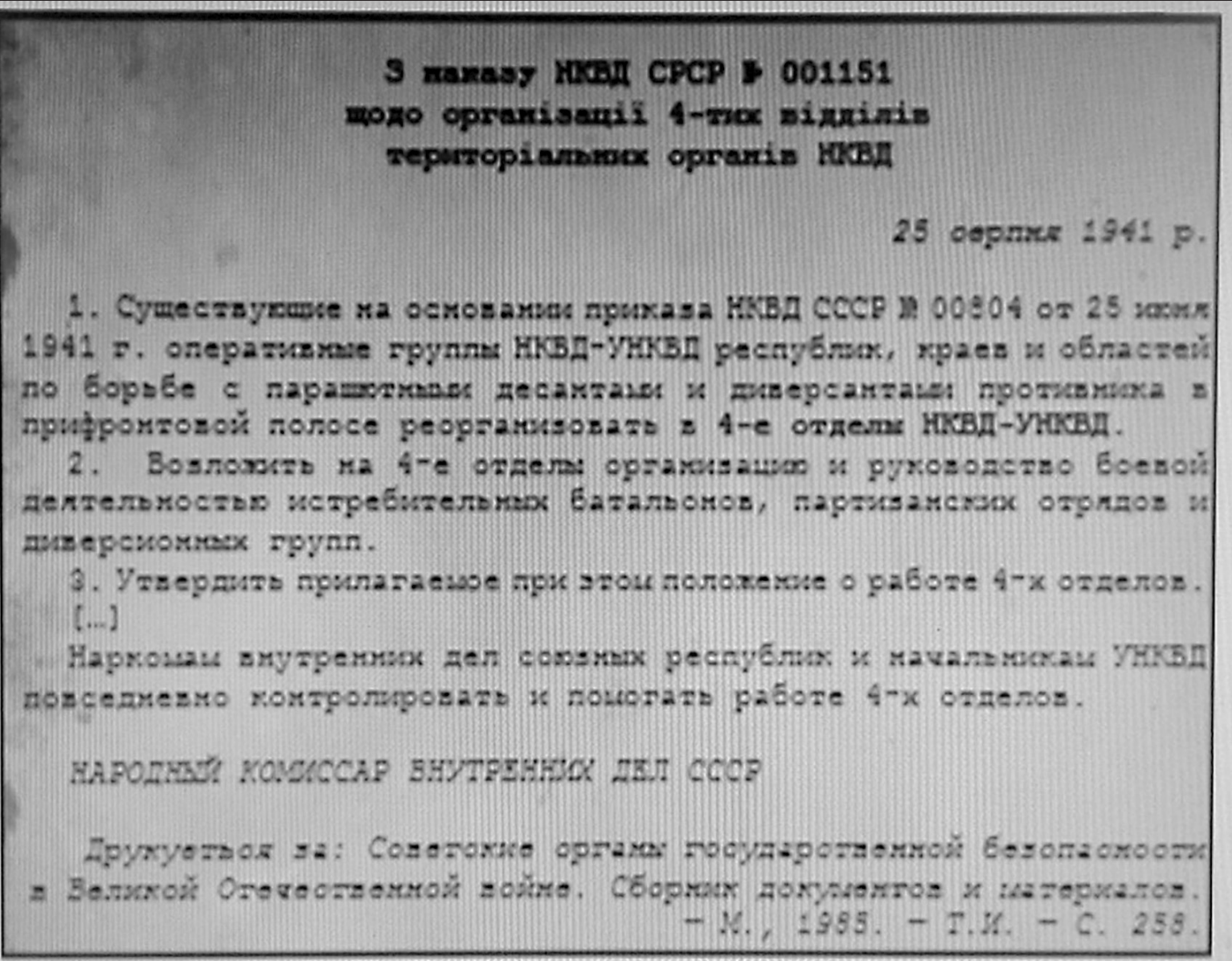

му 1941 р. на базі особливого відділу НКВС СРСР, 17 липня 1941 р. знову перетворюється на Особливий відділ НКВС. Особливі відділи діють при штабах фронтів, об'єднань і з'єднань Збройних сил.

В подальшому відбулася централізація органів держбезпеки та внутрішніх справ. 20 липня 1941 р. НКДБ і НКВС СРСР були об'єднані в єдиний НКВС СРСР. На початку серпня відбулося аналогічне об'єднання органів держбезпеки та внутрішніх справ УРСР.

На базі 1-го управління НКВС СРСР для виконання спеціальних розвідувально-диверсійних завдань у тилу ворога було створено Особливу групу, підпорядковану безпосередньо наркому внутрішніх справ СРСР. Про створення
Особливої групи з ведення зафронтової боротьби при наркомі внутрішніх справ СРСР Л. Берії йдеться в наказі НКВС СРСР № 00882 від 5 липня 1941 року $[1,149]$. Керівником Особливої групи було призначено старшого майора держбезпеки П. Судоплатова. На Групу покладалися такі завдання: розробка i проведення розвідувально-диверсійних операцій проти гітлерівської Німеччини та іiі сателітів; організація підпілля і партизанської війни; створення нелегальних агентурних мереж на окупованій території; керівництво спеціальними радіограмами німецької розвідки 3 метою дезінформації противника.

Для ефективної роботи Особливої групи відбирались досвідчені оперативні співробітники, агенти, формува- 


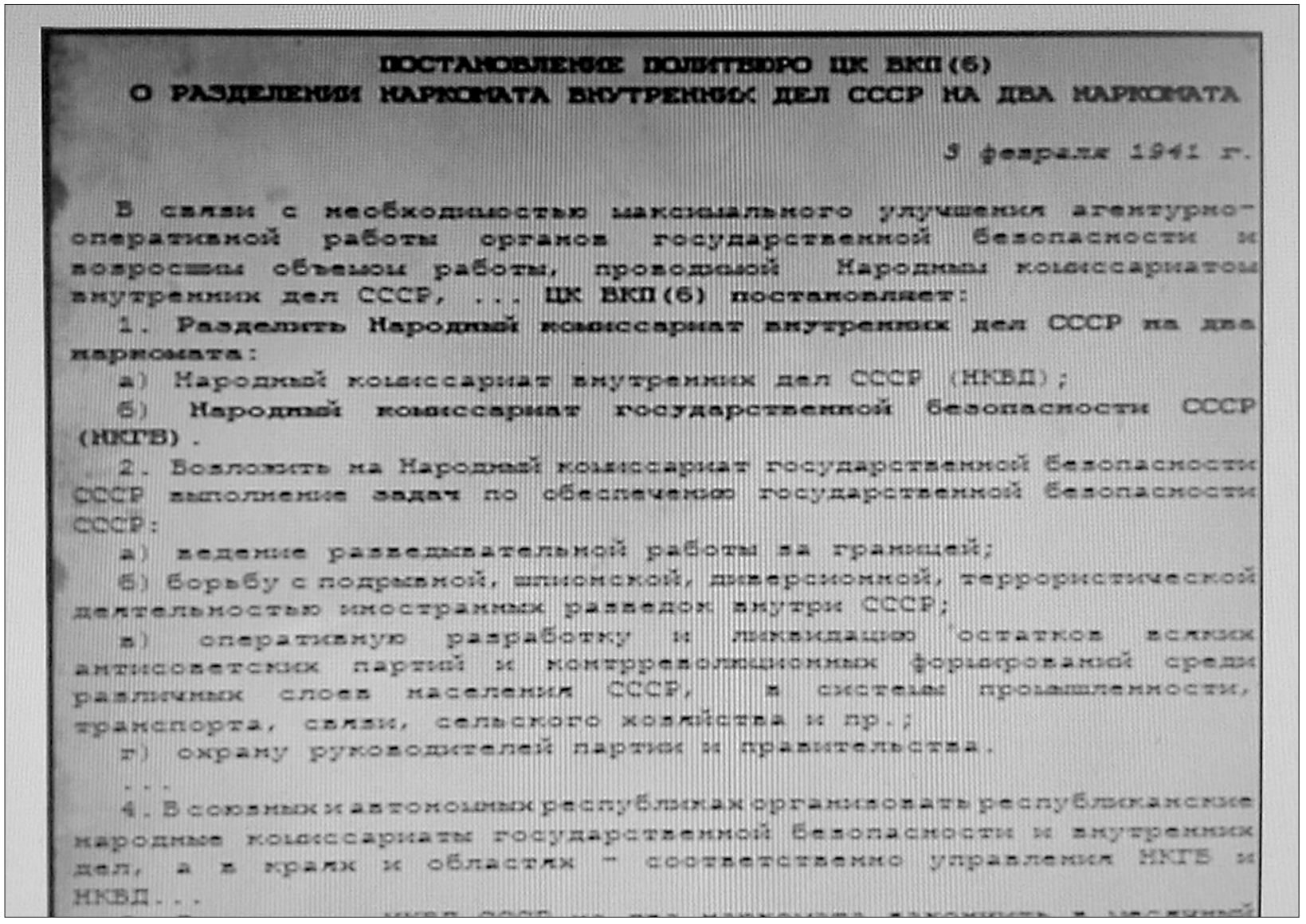

лись резидентури та агентурні групи. У жовтні 1941 р. сформовано Окрему мотострілецьку бригаду особливого призначення НКВС СРСР, завданням якої був збір розвідувальної інформації про війська противника та підготовка загонів для підривної діяльності у ворожому тилу, які згодом ставали ядром великих партизанських з’єднань. В Одесі було створено групу “Форт” В. А. Молодцова, у Миколаєві - “Місцеві” В. А. Лягіна, у Києві - резидентуру “Максим" І. Д. Кудрі [3,117]. Постанова ЦК ВКП (б) "Про організацію боротьби в тилу німецьких військ” від 18 липня 1941 р. хоча і не була нормативним актом, але мала суттєве значення. На підставі цієї постанови розроблялися нормативно-правові акти i будувалася зафронтова робота всіх радянських державних органів, зокрема органів державної безпеки. У Постанові йшлося: “.... для забезпечення широкого розвитку партизанського руху в тилу противника партійні організації повинні негайно організувати бойові дружини i диверсійні групи з числа учасників Громадянської війни і з тих товаришів, які вже проявили себе в винищувальних батальйонах, в загонах народного ополчення, а також із працівників НКВС, НКДБ та ін. ..." [2, 23-24].

Визначальну роль в організації зафронтової і закордонної розвідувальної та розвідувально-диверсійної роботи, розвідувального та контррозвідувального забезпечення партизансько-підпільного руху відіграло 4-те Управління НКВС СРСР. За постановою Раднаркому і ЦК ВКП(б), 25 серпня 1941 р. на- 
казом НКВС СРСР № 001151 оперативні групи місцевих органів держбезпеки були перетворені в 4-ті відділи НКВСУНКВС прифронтових республік (зокрема і УРСР), країв і областей, які займалися організацією партизанської боротьби $[4,518]$.

4-ті республіканські відділи НКВС входили в оперативне підпорядкування Особливій групі при НКВС СРСР. Сама Особлива група зазнала реорганізації. У зв'язку з розширенням об'ємів роботи $з$ організації партизанського руху на окупованій території, 3 жовтня 1941 року відповідно до наказу НКВС СРСР № 001435 "Про організацію 2-го відділу НКВС СРСР" ii було реорганізовано в самостійний 2-й відділ НКВС СРСР 3 безпосереднім підпорядкуванням главі відомства. 10 листопада 1941 р. у складі 2-го відділу запровадили прифронтове відділення із завданням координації спеціальної діяльності за лінією фронту 4-х відділів республіканських НКВС та окремих обласних УНКВС. Це дозволило краще координувати оперативну та бойову діяльність партизанських загонів і розвідувально-диверсійних груп у тилу ворога $[5,163]$.

На початковому етапі німецько-радянської війни, відповідно до вказівки НКВС СРСР від 24 липня 1941 р. щодо питань створення партизанських загонів, у тилу противника партизанські загони створювалися з осіб, які входили до складу винищувальних батальйонів, сформованих за територіальним принципом, працівників НКВС, активістів. Сформовані у липні партизанські пол- ки чисельністю по 1000 осіб кожний, через свою громіздкість не виправдали себе під час виконання бойових завдань і були розформовані. Враховуючи такий досвід, згодом 4-ті відділи НКВС УРСР та відповідних обласних управлінь стали формувати менш чисельні партизанські загони (25-30 осіб).

Четверті підрозділи та їх зафронтові формування упродовж війни слугували провідним інструментом таємного протиборства 3 агресором. На 4-ті відділи зокрема покладалось завдання організації партизанського руху, завдання керівництва діяльністю диверсійних груп. Четверті відділи були створені у 15 обласних Управліннях НКВС УРСР, а згодом невеликі оперативні групи запроваджувалися при штабах армій, що діяли на південному напрямі радянськонімецького фронту. Четверті підрозділи мали здійснювати організацію агентурної та військової розвідки в районах вірогідних дій партизанських загонів та диверсійних груп у тилу противника, керувати діяльністю диверсійних груп, проводити розвідувальне опитування військовополонених, вивчати настрої місцевого населення, взаємодіяти при цьому 3 органами військової контррозвідки, армійським командуванням, партійними організаціями та органами влади.

У положенні про роботу 4-х відділів зазначалося, що свої дії з організації партизанських загонів і диверсійних груп вони координують із особливими відділами НКВС, військовим командуванням, партійними та радянськими 
організаціями. Для здійснення більш тісного контакту між армійським командуванням і 4-ми відділами останні мали своїх представників при штабах армій, фронтів. До завдання представників входило ретельне вивчення обстановки на фронті, районів зосередження противника, розташування його штабів, а також ділянок фронту, де найбільш доцільно проводити перекидання загонів і груп. Аналіз завдань, покладених на 4-ті відділи, доводить, що вони полягали в організації в тилу противника агентурно-військової розвідки, проведення диверсій силами і засобами партизанських загонів і розвідувальнодиверсійних груп [3, 257-258].

18 січня 1942 р. 2-й відділ НКВС СРСР реорганізовується в 4-те (“партизанське”, зафронтова робота) управління НКВС СРСР [6, 45]. У складі наркоматів внутрішніх справ БРСР та УРСР на базі 4-х відділів створювалися власні 4-ті управління. Четвертий відділ НКВС УРСР був реорганізований у 4-те Управління у квітні 1942 p.

Після утворення 4-го Управління НКВС УРСР були уточнені завдання із зафронтової роботи та визначено функціональну спрямованість його апарату. Затверджене наказом НКВС СРСР від 1 червня 1942 р. № 001124 “Положення про роботу 4-х відділів НКВС-УНКВС республік, країв і областей” покладало на них функцію “організації та керівництва агентурно-розвідувальною і диверсійною діяльністю в тилу противника", збирання військово-політичної інформації про становище на окупо- ваній території. Встановлювалося, що здобуту інформацію про розвідувальні та інші спеціальні органи противника, антирадянську діяльність політичних організацій, становище в релігійній сфері та інші значущі відомості мали передаватися до контррозвідувального та секретно-політичного відділів НКВС-УНКВС УРСР.

Серед провідних завдань 4-го Управління визначалися: створення нелегальних резидентур у населених пунктах на окупованій території та забезпечення надійного зв'язку з ними; відновлення взаємодії з найбільш цінною та перевіреною агентурою на окупованій території; запровадження агентури в розвідувальні, адміністративні органи противника та антирадянські організації; підбір та перекидання за лінію фронту кваліфікованої агентури та просування іiі до Німеччини та інших європейських країн; формування та направлення за лінію фронту розвідувально-диверсійних груп, маршрутної агентури; забезпечення зафронтових формувань зброєю, диверсійними засобами, засобами зв'язку тощо [7, 26-27].

У складі 4-го Управління НКВС УРСР існували відділи по напрямам роботи. Перший відділ займався розвідувально-диверсійною роботою на теренах країн-сателітів Німеччини та окупованих гітлерівцями країн Східної Європи; другий - організовував зафронтову роботу на тимчасово окупованій території; третій - займався розгортанням партизанських формувань та їх оперативним забезпеченням (до передачі 
партизанських формувань у підпорядкування Українському штабу партизанського руху у 1942 р.) [8, 36-41].

Поточне керівництво партизанськими силами України 4-те Управління НКВС УРСР здійснювало до 30 травня 1942 р., коли постановою Державного комітету оборони при Ставці Верховного головнокомандувача створили Центральний штаб партизанського руху (ЦШПР), а при Військовій раді Південно-західного напрямку - Український штаб партизанського руху (УШПР) на чолі з колишнім заступником народного комісара внутрішніх справ УРСР Т. Строкачем (29 червня 1942 р.).

Районами дії УШПР визначалися відповідні фронти, Крим (з осені 1942 p. створили Кримський ШПР, підпорядкований УШПР), Західна Україна, Молдова. До липня 1942 р. НКВС УРСР передало у підпорядкування УШПР 1017 партизанських формувань з 25264 учасниками [9, 3]. Відповідно, 4-ті підрозділи переорієнтували винятково на оперативну роботу, на допомогу партизанам у розгортанні розвідувально-диверсійної роботи та налагодженні контррозвідувального захисту партизанських формувань. Конкретні завдання спецслужбі щодо оперативного забезпечення партизанського руху були поставлені у наказі Верховного головнокомандувача від 5 вересня 1942 р. № 00189 "Про завдання партизанського руху”, який мав концептуальне значення для розгортання боротьби в тилу ворога.

У середині 1942 р. Наркомат оборо- ни СРСР затвердив структуру і штати УШПР, які мали і розвідувально-інформаційний (з 26 листопада - розвідувальний) відділ [10, 91]. За згаданим наказом народного комісара оборони СРСР від 5 вересня 1942 р. запроваджувалися посади заступників командирів партизанських загонів із розвідки, на які за лінію фронту направлялися кадрові оперпрацівники НКВС. На цих посадових осіб покладалася організація контррозвідувальної роботи як важливого напряму оперативного забезпечення партизанського руху. Наприкінці 1942 р. німецький тил вже розхитували рейдові з'єднання під командуванням О. Федорова, С. Ковпака, О. Сабурова, М. Наумова.

Звільнення окупованих українських земель та розширення кола службових завдань органів внутрішніх справ потребували структурних змін. Відповідно до указу Президії Верховної Ради СРСР від 14 квітня 1943 року створюється Народний комісаріат державної безпеки (НКДБ) і його республіканські наркомати. Починаючи з 1943 р. удосконалюються форми і методи зафронтової розвідувальної діяльності. Одним із перспективних іï різновидів стали оперативні групи у складі 5-10 осіб, які діяли на базі партизанських загонів для пошуку й знешкодження ворожої агентури. За лінію фронту було відправлено близько 20 оперативних груп ("Переможці”, “За Батьківщину”, “Рейд”, "Дружба", "Вісла" та інші). Зафронтові групи створювали розгалужену агентурно-інформаційну мережу, просува- 
ли власних інформаторів у військові та адміністративні установи окупантів. Створювались також опергрупи 3 кадрових співробітників органів внутрішніх справ та агентів, які виявляли на раніш окупованій території шпигунів, диверсантів та зрадників Батьківщини [11,161]. В Україні згідно з Положенням про функції роботи відділів і відділень 4-го Управління НКДБ УРСР від 12 жовтня 1943 р. керівництво оперативними групами виконувало 1-ше відділення 1-го відділу [13,18-21].

В ході звільнення українських теренів від окупантів головним завданням контррозвідки стала протидія розвідувально-підривній діяльності спецслужб противника та контррозвідувальний захист Червоної армії. 3 цією метою у квітні 1943 р. на базі Особливих відділів НКВС СРСР створено Головне управління контррозвідки (ГУКР) СМЕРШ Наркомату оборони СРСР, підлеглого безпосередньо Верховному Головнокомандувачу. На СМЕРШ покладалися, передовсім, боротьба зі шпигунською, диверсійною, терористичною і підривною діяльністю іноземних розвідок у частинах і з'єднаннях Червоної армії; виявлення "антирадянських елементів" в іiі частинах і установах; боротьба зі зрадництвом і зрадою Вітчизни у частинах і установах Червоної армії; викриття дезертирства; фільтрація та перевірка військовослужбовців та інших осіб, що перебували в полоні і оточенні. Розбудовується мережа оперативних структур військової контррозвідки фронтів, армій, корпусів, дивізій, бри- гад. СМЕРШ діяло у взаємодії з контррозвідниками територіальних органів НКВС-НКДБ.

Одним із основних видів контррозвідувальних заходів радянських спецслужб стали оперативні ігри для дезінформації противника в ході наступальних операцій фронтів.

Після відтворення Народного комісаріату державної безпеки (НКДБ) у 1943 р., одним із напрямів роботи залишалося націоналістичне підпілля. По лінії боротьби з націоналістичним підпіллям продовжувало працювати 4-те Управління. Завдання із протиборства 3 “антирадянськими елементами", відповідно до директиви НКДБ СРСР від 27 травня 1943 р. № 7, отримало і 2-ге (контррозвідувальне) Управління НКДБ СРСР та НКДБ союзних республік. До розробки націоналістичних організацій долучилося i 3-тє (секретно-політичне) Управління НКДБ УРСР $[12,1]$.

Звільнення окупованих територій та вихід на кордони держави поставили нагальне питання відновлення ефективної зовнішньої розвідки. Відповідно до директиви НКДБ УРСР від 28 липня 1944 р. створено 1-ше Управління наркомату (зовнішня розвідка). У 1943-1944 рр. цей підрозділ спромігся придбати низку перспективних оперативних джерел у Німеччині, Австрії й інших європейських державах. До 1948 р. існував ряд закордонних оперативних груп НКДБ-МДБ УРСР, які пізніше стали загальносоюзними резидентурами. Одним із основних завдань 
відтвореного 1-го НКДБ УРСР стала підпільного руху, розвідувальна та розробка закордонних осередків ОУН. контррозвідувальна робота були важУ 1943-1944 рр. цей підрозділ створив ливою ділянкою таємного фронту орнизку оперативних джерел із висвіт- ганів державної безпеки в боротьбі 3 лення діяльності закордонних центрів ворогом. Критичний аналіз діяльності ОУН у Німеччині, Австрії та інших єв- радянських спецслужб у період Другої ропейських державах.

В ході війни протидія розвідувально-диверсійним акціям противника, здобуття цінної військової інформації, та оперативної обстановки. сприяння розгортанню партизанськосвітової війни може бути використаний спецслужбами України в сучасних складних умовах суспільно-політичної

\section{Список використаних джерел і літератури}

1. Судоплатов П. А. Разведка и Кремль. Записки нежелательного свидетеля / П. А. Судоплатов. - М. : Гея, 1996. - с. 149.

2. КПСС в резолюциях и решениях съездов, конференций и пленумов ЦК. - 8-е изд. испр. и доп. - М. : 1971. - Т. 6. - с. 23-24.

3. Советские органы государственной безопасности в Великой Отечественной войне. Сб. документов и материалов. М.:1985. -Т. 2. - с.117.

4. Органы государственной безопасности СССР в Великой Отечественной войне : сборник документов : в 8 т. Т. 2, Кн. 1.- М. : Русь, 2000. - с. 518.

5. Органы государственной безопасности СССР в Великой Отечественной войне : сборник документов : в 8 т. Т. 1. Кн. 2. - М. : Русь, 2000. - с. 163.

6. Головний державний архів Служби безпеки України ( далі ГДА СБУ). - Ф. 60. Спр.86751. - Т. 46. - Арк. 45.

7. ГДА СБУ. - Ф. 60. - Спр. 86751. - Т. 46. - Арк. 26-27.

8. ГДА СБУ. - Ф. 60. - Спр. 86751. - Т. 46. - Арк. 36. 41.

9. ГДА СБУ. - Ф. 13. - Спр. 507. - Арк. 3.

10. Кентій А., Лозицький В. Війна без пощади і милосердя: Партизанський фронт у тилу вермахту в Україні (1941-1944). - К. : 2005. - с. 91.

11. 3 архівів ВУЧК-ГПУ-НКВД-КГБ : науковий і документальний журнал. - К. :, 2000. № 1 (спецвипуск). - 264 с. - с. 161.

12. ГДА СБУ. - Ф. 9. - Спр. 18. - Арк.1.

13. ГДА СБУ - ф. 60. - Спр. 883529. Част. 1. - Арк. 18-21. 


\section{References}

1. Sudoplatov P.A. (1996). Intelligence and the Kremlin. Notes of an unwanted witness / P.A. Shipboards. Moskow. 149.[in Russian].

2. CPSU in resolutions and decisions of congresses, conferences and plenums of the Central Committee. - 8th ed. dispatch and ext. (1971). Moskow. 23-24. [in Russian].

3. Soviet State Security Authorities in the Great Patriotic War. Sat. documents and materials. (1985). Moskow. 117. [in Russian].

4. USSR State Security Authorities in the Great Patriotic War: Collection of Documents. (2000). in 8 vols. Vol. 2, Bk. 1. Moskow. 518. [in Russian].

5. State Security Authorities of the USSR in the Great Patriotic War: Collection of Documents. (2000).in 8 vols. Vol. 2, Bk. 2. Moskow. 163. [in Russian].

6. Main State Archives of the Security Service of Ukraine (State Archives SBU). - F. 60. Ref.86751. - Vol. 46. - Ark. 45.

7. State Archives SBU. - F.60. - Ref.86751. - Vol.46. - Ark. 26-27.

8. State Archives SBU. - F.60. - Ref.86751. - Vol.46. - Ark. 36-41.

9. State Archives SBU. - F. 13. - Ref . 507. - Ark. 3.

10. Kentiy A., Lozitsky V. (2005).War without mercy and mercy: The guerrilla front in the rear of the Wehrmacht in Ukraine (1941-1944). Kyiv.91.[in Ukrainian].

11. From the archives of VUCHK-GPU-NKVD-KGB: scientific and documentary journal. (2000). № 1 (special issue). - Kyiv. 161.[in Ukrainian].

12. State Archives SBU . - F.9. - Ref. 18. - Ark.1.

13. State Archives SBU.- F.60. - Ref. 883529, Part. 1. - Ark. 18-21.

Khodanovich A. L., Candidate of Historical Sciences, Associate Professor, Professor of the Department of Theory and History of State and Law of the National Academy of Security Service of Ukraine, Kyiv

\section{ORGANIZATIONAL RESTRUCTURING OF COMMITTEE FOR STATE SECURITY OF THE UKRAINIAN SSR DURING THE SECOND WORLD WAR}

The military-political situation during the Second world war was being negotiated by organizational and structural changes of the Soviet state security bodies in Ukraine.

Historiographical palette of domestic research on the history of the Soviet secret police in Ukraine in the period of the Second world war is quite broad. This archaeo- 
logical research, publications of a General nature, the study of the punitive-repressive activities and biography. The most relevant to the stated subject of the article the scientific groundwork for the functioning of the Soviet state security bodies. Normativelegal bases of activity investigated in the dissertation research of L. Borodzicz, A. Oleinik, A. Lebedev, A. articles God. A. Kalyuka. The creation of the Soviet state security bodies in Western Ukraine covered in articles D. Vedeneeva. I. Losa, A. Wheat. Analyzed the impact of the operational situation during the war on the formation of structures of military intelligence in the thesis.Bykhov, Features counter the German counter-intelligence agents investigated in the works of Tchaikovsky. Publications D. Vedeneeva, G. Bystrukha analyzed vneplanovo work and organization of the Soviet intelligence guerrilla warfare behind enemy lines. the public security organs. However, the period of the Second world war and still remains one of Dolci stages of the history of the Soviet secret police.

The aim of this article is to attempt a synthesis of scientific progress on the restructuring of the Soviet state security bodies in Ukraine during the Second world war, to consider the legal basis for restructuring and measures of state security bodies since the beginning of the Second world war and the wartime conditions.

Keywords: the organs of state security, a Special group, and 4 divisions, the 4th Department of the NKVD, organs of military counterintelligence, Safronova work, operational support of the guerrilla movement, reconnaissance and sabotage operations. 